\title{
Determinants of the Financial Literacy among College Students in Malaysia
}

\author{
Muhammad I. Albeerdy ${ }^{1} \&$ Behrooz Gharleghi ${ }^{1,2}$ \\ ${ }^{1}$ Faculty of Business and Management, Asia Pacific University of Technology and Innovation, Kuala Lumpur, \\ Malaysia \\ ${ }^{2}$ Centre of Socio-Economics of Ageing (CSEA), Asia Pacific University of Technology and Innovation, Kuala \\ Lumpur, Malaysia \\ Correspondence: Behrooz Gharleghi, PhD., Faculty of Business and Management, Asia Pacific University of \\ Technology and Innovation, TPM, 57000, Bukit Jail, Kuala Lumpur, Malaysia. Tel: 60-19-615-3515. E-mail: \\ Gharleghi.bn@gmail.com
}

Received: February 23, 2015

Accepted: March 26, 2015

Online Published: April 20, 2015

doi:10.5430/ijba.v6n3p15

URL: http://dx.doi.org/10.5430/ijba.v6n3p15

\begin{abstract}
Objective: The purpose of this study is to investigate the factors influencing the financial literacy among university students in Malaysia.

Methods: Data for this study was collected through self-administered questionnaire and distributed through convenient sampling method. A total of 105 completed and usable questionnaires have been collected. Pearson Correlation analysis and multiple regression tables were used to determine the interrelation of different variables in financial literacy.

Results: Empirical results show that there is a significant relationship between independent variables of education, and money attitude towards the dependent variable of financial literacy, while there found no relationship between financial socialization agents and financial literacy.
\end{abstract}

Conclusions: This study is important so as to understand how these independent variables affect the literacy rate of young adults. Efforts may be put to strengthen those variables in order increase the literacy rates of those university students.

Keywords: education, financial socialization agents, money attitude, financial literacy

\section{Introduction}

Financial literacy was defined by Noctor, Stoney and Stradling (1992) as 'the ability to make informed judgements and to take effective decisions regarding the use and management of money'. Being financially literate would mean that an individual would benefit from a palette of abilities and attitudes such as a comprehension of money management concept, knowledge of financial institutions and attitudes which enable effective and responsible management of financial affairs. These benefits was previously identified by Schagen and Lines (1996, p. 91).

Moreover, students are poised to have a spending behaviour similar to their family, thus one of the financial socialization agents. They grow up in a certain environment depending on the family background where they have this benchmark set by their parents. They will be automatically influenced by how their respective parents manage and spend their money as they will grow up with the same culture and principle. The degree of financial literacy of the family will eventually have an impact on the student at an early stage and it is up to the family to foster this literacy to their underlings. Another motivator of financial literacy of students will be the attitude towards money. This factor will differentiate each students corresponding to the degree they deem money to be important. Individuals will want to be financially literate depending on how much they value money.

Malaysia College students became a lucrative consumer market segment as the number of students enrolled in tertiary education tripled between 1999 and 2005. As the standard of living in Malaysia has improved significantly and stimulated changing lifestyles, college students today are granted greater freedom from their parents to make their own shopping and consumption decisions (Kamaruddin \& Mokhlis, 2003). Based on this finding, the student 
must have an adequate financial knowledge in order to make the best possible decisions financially or if not, this will result in a conspicuous consumption and will further lead to poor financial management. Poor financial management can affect student's academic performance, mental and physical well-being, and even the ability to find employment after graduation (Bodvarsson and Walker, 2004 and Lyons, 2004).

If individuals are to navigate the current financial landscape, there is an increasing need for financial knowledge and at minimum basic financial skills (Morris 2001). Report and evidences show that financially educated society enables individual to better make financial decisions. With the students being more prone to make financial decisions, there are more risks for them to make a bad call and abysmal decisions may be taken. To reduce the risk of poor decision making financial education and awareness becomes pivotal (Widdowson \& Hailwood 2007). Students must be sensitized in such a way that they receive proper education towards financial management in order for them to get a grasp on their spending behaviour and habits for the future. Educational institutes has for aim to properly shape an individual so that he/she can adapt and survive in the real world and why is these institutes not the first body to consider when there is a need for the students to be financially literate.

Beutler and Dickson (2008) stated that failure to adequately socialize young people for adult financial roles is costly at both individual and societal levels. "When they turn 18, we give young adults the full rights to make contracts, obtain loans, secure housing, work full time and fight for their country. Underpinning all of these very adult responsibilities are financial choices. Yet far too few of these young people are ever taught to manage money.

Financial socialization theory says that "socialization takes place through interaction of the person and various agents in specific social settings" (McLeod \& O'Keefe, 1972, p.135). People who interacts within a social setting is called the socialization agents and these agents may have an influence on the spending behaviour and management of an individual. A primary assumption inherent in the socialization perspective is that to understand how consumers shape their knowledge and behaviour, it is important to specify the influence of socialization agents and to examine the processes by which consumers acquire such knowledge and behaviour (Churchill \& Moschis, 1979). Because the Malaysian consumer market has changed considerably, the role of parents for monitoring their children's consumption habits has become more critical and parents' characteristics may also be related to the development of their children's financial knowledge and behaviour (Clarke, Heaton, Israelsen, \& Egget, 2009).

In today's generation, youngsters tend to value money more than compared to previous generations whereby older generations were not interested in the materialistic world as the younger generations nowadays. However, the attitude an individual has over money will eventually affect his/her literacy and behaviour towards finance. People who view money as just a measure to obtain their immediate wants will never be able to have a proper financial planning for the future which is the main problem in this modern era. Thus, individuals having the right attitude and mind-set towards money will be more prone in an early financial planning and savings. This will hinder their chances of going bankrupt or fail to enjoy the benefits of an early financial savings.

The utmost concern should be raised concerning the financial literacy among students as it eventually will affect one's welfare, especially in their later stages of life when they reach retirement during which they should be benefiting from financial planning and savings. Moreover, financially illiterate individuals tend to adopt welfare-reducing decisions such as keeping large outstanding debts on credit cards when they have cheaper alternatives which they fail to know due to their lack of knowledge.

Based on the discussion above, this paper has three objectives to be achieved using techniques that will be introduced afterwards;

Objective no 1: To identify whether there is any effect from education towards financial literacy among college students in Malaysia.

Objective no 2: To identify whether there is any effect from financial socialization agents towards financial literacy among college students in Malaysia.

Objective no 3: To identify whether there is any effect from money attitudes towards financial literacy among college students in Malaysia.

\section{Literature Review}

\subsection{Education towards Financial Literacy}

'Financial literacy is both an important life skill and a critical intellectual competency' and 'an essential component of a college degree'. (Kezar and Yang, 2010:15). It is only logical that students must be educated at one point of their life on how to act on spending the money they will obtain at a later stage of life and where else to educate them if not 
in college. As per the US National Jumpstart Coalition survey in 2006, students who attended high school personal finance course were poised to do better on the national standardised financial literacy test than those who did not attend those courses. These statistics might be encouraging for the United States as it shows that education can play a part for students in understanding how to effectively use their monetary resources. As these projects were then made in foreign countries, Malaysia must also take the leap to provide financial course to their students so as to enjoy the advantages of having a financially literate younger generation.

Also Staten, Elliehausen, and Lindquist (2002) reports that students who were enrolled in credit counselling were able to reduce their debts and they even have a better grasp on their credit card management which allow them to further reduce their debts. As we all know, without informing students about the possible outcomes of using credit cards, they will use this source without taking into account the amount of debts they can accumulate. Hence, it is the duty of educational institute to intervene and counsels these youngsters about how to properly use credit cards and inform them about debts they may obtain.

Logically there is the argument that personal finance should be part of basic education of all students (Mandell 2008; 2009), and most developed nations have adopted or aim to mandate financial education as part of the kindergarten-year 12 curriculum (OECD 2005). This promotes the importance of education towards an early age so that the students will have a better shape of education knowledge and management in the future. Additional research that has focused on youth and financial literacy education has also provided evidence that formal courses in personal finance can increase financial knowledge, and often result in more positive financial behaviour. Therefore, it enables students to have a better behaviour as a consumer in the future when they are faced with choices from different product and services.

Lawmakers had no way of knowing in 2007 that the U.S economic situation would be where it is today, making financial education for students now even more crucial than at any other time in recent history. Lawmakers did not predict the consequences of lack of financial education can have on financial literacy of the country and now they understand how crucial it is to provide financial education in order to avoid the same mistake again.

\subsection{Financial Socialization Agents towards Financial Literacy}

Financial socialization is a process by which individuals acquire from the environment those skills, knowledge, and attitudes that are necessary to maximize their consumer role in the financial marketplace (Ward, 1974). The main agents for student's socialization are peer groups, family, schools and media and all of them occur at one point of time throughout an individual's life cycle. The following discussion will relate to how these financial socialization agents (i.e., peer groups, family and media) have an influence on financial literacy among students.

In a study conducted by Churchill and Moschis (1979), it is reported that family interaction about financial management declines over age and that peer communication about financial matters increases with age. This report highlights the importance of these two agents over a particular period of an individual. The family is credited with being a major source of children's socialization; children through observing their parents, participating in financial practices, and receiving direct instruction (Beutler \& Dickson, 2008; Pinto, Parent, \& Mansfield, 2005). A student's family will always be his/her first shelter and role model. Parents influence their children overtly and cognitively through direct teaching, reinforcement and purposive modelling (Moschis, 1987). Children have already acquired knowledge, attitudes, and motives on most subjects that might be included in education about the consumer role before coming into the classroom. This is to show that family, especially parents, have a huge impact on the financial behaviour and literacy of an individual. The degree of education towards finance of a parent will automatically be inculcated to their children and the children will inevitably try and reciprocate this behaviour. Children learn financial management behaviour through observations and participation (incidental learning) and through intentional instruction by socialization agents (Danes \& Dunrud, 1993; Moschis, 1987; Rettig \& Mortenson, 1986). If the parents are responsible enough to inculcate their values of financial knowledge to their child, the latter will be financially literate even before going to school attending financial literacy curriculums.

In a study conducted by Buijzen \& Valkenburg (2003), it was reported that $33 \%$ of college and high schools students use media or internet as a mean to seek financial knowledge. Research has shown that the amount of television viewed is positively related to adolescents' purchase requests, brand recognition, materialistic attitudes, and financial behaviours. By analysing the study, we find that students think that the media is a medium for them to become financially literate. They do not abide by the conventional ways of learning money management from schools; on the other hand, they trust the media (i.e., television, internet, advertisements, and newspaper) on how to spend their money. 
Previous research has emphasized that parents, peers, printed media, television commercials, and in - school education are the most important agents of consumer socialization (Chan \& McNeal, 2006). Hence, it can be considered that childhood consumer experience, personal and family background and student characteristics may have an important role on financial literacy as an outcome among students in Malaysia.

\subsection{Money Attitude towards Financial Literacy}

Money is an important issue for people, not only as a utilitarian commodity but also as an emotional representation of worth or through symbolic meanings (Engelberg \& Sjoberg, 2006). Furthermore, money has been recognized as a powerful motivator of behaviour (e.g., as a force leading to productivity in organizations), as well as a factor that shapes job satisfaction and stress. This is to say that your attitude towards money may shape your knowledge financially. How someone value money will eventually have an impact on his/her literacy financially. One's thought about money will as a result influence his/her ability on money management. Consequently, having a positive attitude towards money will influence someone to have a more financial understanding and literacy whereas a negative attitude will lead to poor management, knowledge and financial ruin. In a study among college students, Edwards et. al (2007) highlights that money attitude is related to children being open about their financial situation with their parents. By having a positive attitude towards money, students will feel concern about their current situation and they will want to know how to successfully manage the finance in order to remain stable. They will have a proper interaction about financial matters with their parents.

Specific money attitudes were related to self-direction and security values, implying that those attitudes likely interact with a self-directed behaviour for security such as financial knowledge seeking (Burgess, 2005). It all depends on how the students value money or financial security in order for them to seek knowledge about how to manage their savings and spending. This may trigger the need for youngsters to acquire skills required for having a better ability in terms of financial behaviour and literacy.

Moreover, in this modern society, religious and moral values are becoming less important and the world is turning into a more materialistic importance whereby youngsters are more concerned with earning money rather than believing in conventional beliefs of their forefathers. Thus, money is an important aspect of one's life nowadays and this may act as motivation for students in order to become more financially literate than previous generations. Kim (2003) later identified money as a tool of safety which triggers the motivation for a better money management in the future. Everyone wants to be safe financially and without being properly literate financially, it would be a waste of time.

Kidwell and Turrisi (2004) researched on the budgeting tendencies of students and found that those students who were highly confident about their skill to keep a budget were likely to justify reasons for budget. These students perceive money as "normative expectancies". Contrarily, those students who had lower perceived control over their budget relied on their emotional feelings towards budgeting, rather than their cognitive beliefs about budgeting. As we can see, it will depend on how the student perceives money in order for them to be able to set an appropriate budget for themselves. If an individual value money and know that this is one of the most important assets he/she can possess, then they will do their maximum to maintain a particular budget in order to smoothen their expenses. Relying on emotional feelings for keeping a record of one's budget is fruitless as it will result only into failure in maintaining a good record of one's transactions.

\subsection{Financial Literacy}

Financial literacy can be generally defined as a person's ability to understand, analyse, manage, and communicate personal finance matters (Vitt et al., 2000). Financial literacy is when an individual have the ability and skills to have a proper knowledge about financial matters. Low level of financial literacy may lead to bad financial decision making and this may result into many problems such as debts or even bankruptcy. This often results in financial behaviours varying greatly from recommended guidelines, which, in turn, contributes to low levels of financial well-being (Hilgert, Hogarth, \& Beverly, 2003).

The Ministerial Council for Education, Early Childhood Development, and Youth Affairs (MCEECDYA) in Australia defines Financial literacy as 'the application of knowledge, understanding, skills and values in ... financial contexts and the related decisions that impact on self, others, the community and the environment'. This finding gives us an insight that financial literacy has an impact not only on the individual, but on the society as well as the environment.

Financial literacy is fundamental for young adults when they are exposed to an array of financial products and services where they need to choose whilst embarking on their own major financial life cycle events such as acquiring a job, earning their first salaries, secure student loans or managing their credit card spending's. In addition, lifestyle 
aspirations spurred on by the influence of advertising and the media are also likely to increase young people's reliance on debt (Fear and O'Brien 2009). Hence, it is of great importance that young students or adults are financially literate and prepared so that the best financial decisions are taken.

The first year of college constitutes an especially important transitional stage of development within the larger transitional period because most college students are not yet financially independent but are actively learning the skills needed to be financially independent. Furthermore, they perceive this independence as key to achieving adult status (Arnett 2004). If these youngsters are not provided a suitable financial literacy curriculum, they will not have the support needed for them to enhance their skills in purchasing behaviour and savings whereby they can jeopardise their potential of accumulating wealth at an early stage.

\section{Research Methodology}

\subsection{Research Framework}

Following diagram shows how Education, Financial Socialization Agents and Money Attitude affect the Financial Literacy among College students in Malaysia.

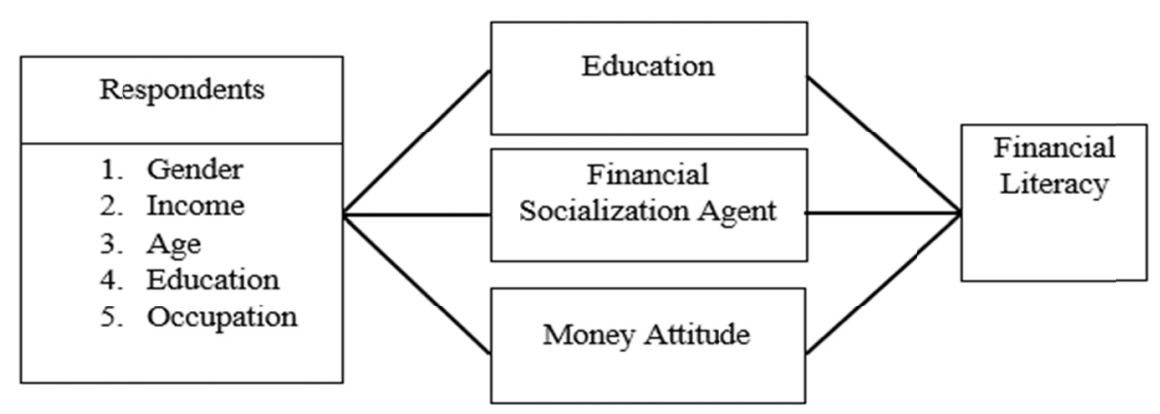

Figure 1. Research framework

\subsection{Research Design Sampling Population}

This study can be considered as a quantitative and exploratory study, the population related with this study is based on Malaysia. The sample of this study will analyse the level of financial literacy among students in Malaysia. In terms of sampling methodology, this study had used convenience sampling methodology. We will take a sample of 105 students in Malaysia.

\subsection{Data Collection Method}

Data collection is the process of obtaining the information requisite for the research. In this section, the researcher will devise techniques in which the latter will be able to gather information. The information collected is considered to be primary data using survey. A set of questionnaires will be handed-out face-to-face as well as through different online sources. Online questionnaires will be an easy and fast way to obtain the primary data given, thus the questionnaires will be both on hardcopy and softcopy. 25 copies will be handed face-to-face and 80 will be provided online so that the students all around Malaysia can get access to.

\subsection{Data Analysis and Interpretation}

The total numbers of 105 respondent details are keyed into SPSS one by one, and then the individual data will be analysed on a group basis. In this research paper, the statistic will include both of the descriptive and inferential statistics. This study employed Cronbach alpha, the Pearson Moment Correlation test, and regression test to examine the relationship between the variables.

\section{Empirical Findings}

\subsection{Reliability Test}

The reliability test is a consistent measurement to examine the reliability when we have same respondents, so this test provides the standard level of accuracy for variables. "Cronbach alpha" test in SPSS is used and the standard rate 
for this test is 0.70 ; it means that if the value of reliability of data is more than 0.70 , the variables and data are reliable. Empirical finding on this test are presented in following table:

Table 1. Cornbach alpha test

\begin{tabular}{ll}
\hline Variable & Value \\
\hline Education & 0.860 \\
Financial Socialisation Agents & 0.889 \\
Money Attitude & 0.861 \\
Financial Literacy & 0.776 \\
All variables & 0.873 \\
\hline
\end{tabular}

According to the Table 1, all variables and data are reliable and we can proceed with the next step which correlation and regression tests.

\subsection{Pearson Correlation Analysis}

The Correlation is used to look at the 'net strength' relationship between two continuous variables. Pearson product-moment correlation coefficient is the correlation coefficient which conducted to view the correlation between variables from the range of 0 to 1 . When the value is close to 0 , it represents a little or absolutely no correlation between variables. We have used the following critical values to measure the correlation between the variables.

Table 2. Pearson correlation critical values

\begin{tabular}{ll}
\hline Value of the Correlation Coefficient & Strength of Correlation \\
\hline 1 & Perfect \\
\hline $0.7-0.9$ & Strong \\
\hline $0.4-0.6$ & Moderate \\
\hline $0.1-0.3$ & Weak \\
\hline 0 & Zero \\
\hline
\end{tabular}

\subsection{Pearson Correlation Results}

Table 3. Pearson correlation results

\begin{tabular}{lccc}
\hline & Education & Financial Socialisation & Money Attitude \\
\hline Pearson Correlation & $.774^{* *}$ & .123 & $.714^{* *}$ \\
Sig. (2-tailed) & .000 & .212 & .000 \\
$\mathrm{~N}$ & 105 & 105 & 105 \\
\hline
\end{tabular}

** denotes sig at $5 \%$

\subsection{Relationship between Education and Financial Literacy}

Information in the Table 3 shows that the Pearson correlation between education and financial literacy value is positive. The Pearson Correlation value which is 0.774 and the $p$-value is 0.000 where $\mathrm{P}<0.05$. The result shows that there is a relationship between education and financial literacy. Since the Pearson Correlation value (r) is 0.774 and it is nearly to 1, according to Table 2 (Danceys and Reidy's, 2004), the relationship between education and financial literacy is considered very strong and positive. 


\subsection{Correlation between Financial Socialization Agents and Financial Literacy}

Information in the Table 3 shows that the Pearson correlation between financial socialization agents and financial literacy value is positive. The Pearson Correlation value is 0.123 and the $p$-value 0.212 where $\mathrm{P}>0.05$. The result shows that there is a relationship between the two variables namely, financial socialization agents and financial literacy. Since the Pearson Correlation value (r) is 0.123 and it is nearer to 0, therefore, the relationship between financial socialization and financial literacy is consider weak but there is a positive correlation.

\subsection{Correlation between Money Attitude and Financial Literacy}

Information in the Table 3 shows that the Pearson correlation between money attitude and Financial Literacy value is positive. The Pearson Correlation value which is 0.714 and the $\mathrm{p}$-value was 0.000 where $\mathrm{P}<0.05$. The result shows that there is a relationship between the two variables namely, money attitude and financial literacy. Since the Pearson correlation value (r) is 0.714 and it is nearer to 1 , therefore, the relationship between those two variables is considered very strong and positive.

\subsection{Regression Analysis}

Table 4. Model summary

\begin{tabular}{ccccc}
\hline Model & $\mathrm{R}$ & $\mathrm{R} 2$ & Adjusted R2 & Std. Error of the Estimate \\
\hline 1 & $.846 \mathrm{a}$ & .715 & .707 & .48268 \\
\hline
\end{tabular}

a. Predictors: (Constant), IV2, IV3, IV1

According from the table above, it shows that the coefficient determination of $\mathrm{R}$ Square is 0.715 . It indicates that education, financial socialization agents and money attitude have contributed up to $71.5 \%$ towards financial literacy among university students in Malaysia. On the other hand, $28.5 \%(100-71.5)$ identify as the elastic factors that is uncontrollable.

4.8 ANOVA Analysis

Table 5. ANOVA analysis

\begin{tabular}{lccccc}
\hline ANOVA $^{\mathrm{a}}$ & Sum of Squares & df & Mean Square & F & Sig. \\
\hline Regression & 59.144 & 3 & 19.715 & 84.618 & .000 \\
Residuals & 23.531 & 101 & .233 & & \\
Total & 82.675 & 104 & & & \\
\hline dependent Variable: Financial Literacy \\
predictors: (constant), Education, Financial Socialisation Agents, Money Attitude \\
\hline
\end{tabular}

Based on the table above, the $\mathrm{F}$ value is 84.618 is significant at the level of $0.000(\mathrm{p}<0.05)$. Hence, the overall regression model for education, financial socialization agents and money attitude is working properly in explaining the difference in financial literacy among university students in Malaysia.

\subsection{Regression Coefficients}

Table 6. Regression analysis

\begin{tabular}{|c|c|c|c|c|c|}
\hline \multirow[t]{2}{*}{ Model } & \multicolumn{2}{|c|}{$\begin{array}{l}\text { Unstandardized } \\
\text { Coefficients }\end{array}$} & \multirow{2}{*}{$\begin{array}{c}\begin{array}{c}\text { Standardized } \\
\text { Coefficients }\end{array} \\
\text { Beta }\end{array}$} & \multirow[t]{2}{*}{ t-stat. } & \multirow[t]{2}{*}{ Sig. } \\
\hline & Beta & Std. Error & & & \\
\hline (Constant) & .111 & .322 & & .347 & .730 \\
\hline Education & .410 & .080 & .401 & 5.091 & .000 \\
\hline Financial Socialisation Agents & .023 & .023 & .052 & .968 & .335 \\
\hline Money Attitude & .441 & .069 & .501 & 6.413 & .000 \\
\hline
\end{tabular}

Dependent variable: Financial Literacy 
The formula used to identify the beta value of standardized coefficients is stated below and it shows how each of the independent variables (Education, Financial Socialization Agents and Money Attitude) has an impact on the dependent variable (Financial Literacy):

\section{Financial Literacy $=0.111+0.401$ Education +0.052 Financial Socialization Agents +0.501 Money Attitude}

From the coefficients table above, education has a significant positive influence towards financial literacy among university students $(\mathrm{p}=0.000, \mathrm{t}=5.091, \beta=0.401)$. If education increases by one unit, it will eventually increase the financial literacy among university students by 0.401 .

The hypothesis related to this variable is written in for of null and we can conclude that the null hypothesis is rejected. H0: There is no relationship between the Education and Financial literacy.

Bernheim, Garrett, and Maki (2001), for example, provided evidence on the long-term behavioural effects of high school financial education by showing that mandated school financial education significantly increases saving rates at the household level and wealth levels over the course of the lifespan. In 2005, Varcoe, Martin, Devitto, and Go noted that using a professionally designed financial curriculum improved the financial knowledge and behaviour of high school students.

However, financial socialization agents do not have a significant influence towards the financial literacy among university students even if the correlation is positive. The data are $\mathrm{p}=0.335, \mathrm{t}=0.968, \beta=0.052$. The hypothesis related to this variable is written in null form in below and it is accepted. H0: There is no relationship between Financial Socialization Agents and financial literacy

Based on the data collected, it can be seen that family was the main socialization agent that students deem for them to be financially literate. Family was picked by 61 responders or $58.2 \%$. Family, especially parents, is known to be one of the primary socialization agents for youth when shaping money or saving attitudes (Clarke, Heaton, Israelsen, \& Eggett, 2005). Consider the study by Lyons (2004) in which they surveyed high school and college students who participated in a financial education workshop. Their results showed that almost $77 \%$ of the students had turned to their parents to obtain financial information. These socialization agents, especially family and peers played a great role in shaping the financial knowledge of these youngsters as can be seen through observation of the data collected. This suggests that the exposure to these socialization agents will impact the literacy rate of those students, the more they are interacting with the agents, the more knowledgeable the students will be and vice-versa.

Furthermore, money attitude also has a significant positive influence towards the financial literacy among university students. The data are $\mathrm{p}=0.000, \mathrm{t}=6.413, \beta=0.501$. If money attitude increases by one unit, it will increase the financial literacy among university students by 0.501 . the null hypothesis for this variable is written as below and hence it is rejected. H0: There is no relationship between Money Attitude and financial literacy.

Based on previous research and current findings, it can be said that money attitude has a significant impact on financial literacy of university youngsters. Having a good attitude towards money will enhance the willingness of individuals to properly manage their finances as compared if they perceive money in a different way. Hence, if an individual's perception about money is negative, there will not be an effort in learning how to properly manage their finances.

\section{Conclusion}

To conclude, we can observe that education, financial socialization agents and money attitude have a direct influence of financial literacy rates among students in Malaysia. Education was proven to have the strongest influence on the financial knowledge of university students. Varcoe, Martin, Devitto, and Go, 2005 noted that education is a significant factor in shaping the financial knowledge and behaviour of youngsters and it is also only logical to understand that for a better comprehension of a matter, education must be primarily opted. Money attitude was also found to have a strong positive influence on the financial literacy of youngsters. Based on previous researches, the National Jumpstart Coalition Survey done in 2006 for Korean students concluded that money attitudes were found to be the most significant predictor of Korean high school students' financial literacy. The result showing a relationship between money attitudes and financial literacy was consistent with findings reported by Hong (2005) and Kim (2003). Financial socialization agents also proved to have an influence on the literacy rates of young adults. Based on current finding, it can be seen that family had the main influence for youngsters in terms of managing their money followed by Peers. 


\section{References}

Arnett, J. J. (2000). Emerging adulthood: A theory of development from the late teens through the twenties. American Psychologist, 55(3), 469-480. http://dx.doi.org/10.1037/0003-066X.55.5.469

Bernheim, B. D., Garrett, D. M., \& Maki, D. M. (2001). Education and Saving: The Long-Term Effects of High School Financial Curriculum Mandates. Journal of Public Economics, 80(3), 435-465. http://dx.doi.org/10.1016/S0047-2727(00)00120-1

Beutler, I., Beutler, L., \& McCoy, J. (2008). Money aspirations about living well : Middleschool student perceptions. Financial Counseling\& Planning, 19(1), 44-60. Retrieved March 10, 2009, from Academic Search Complete database.

Bodvarsson, O. B., \& Walker, R. L. (2004). Do parental cash transfers weaken performance in college? Economics of Education Review, 23(5), 483-495. http://dx.doi.org/10.1016/j.econedurev.2003.11.009

Buijzen, M., \& Valkenburg, P. M. (2003). The impact of television advertising on children's Christmas wishes. Journal of Broadcasting \& Electronic Media, 44, 456-471. http://dx.doi.org/10.1207/s15506878jobem4403_7

Burgess, S. M. (2005). The importance and motivational content of money attitudes: South Africans with living standards similar to those in industrialized Western countries. South African Journal of Psychology, 35, $106-126$. http://dx.doi.org/10.1177/008124630503500107

Chan, K., \& McNeal, J. U. (2006). Rural chinese children as consumers: Consumption experience and information sources. Journal of consumer behaviour: An international Review, 5, 182-192. http://dx.doi.org/10.1002/cb.170

Churchill, G. A., \& Moschis, G. P. (1979). Television and interpersonal influences on adolescent consumer learning. Journal of Consumer Research, 6, 23-35. http://dx.doi.org/10.1086/208745

Clarke, M. D., Heaton, M. B., Israelsen, C. L., \& Eggett, D. L. (2005). The acquisition of family financial roles and responsibilities. Family and Consumer Sciences. http://dx.doi.org/10.1177/1077727X04274117

Dancey, C., \& Reidy, J. (2004). Statistics without Maths for Psychology: using SPSS for Window. London: Prentice Hall.

Danes, S. (1994). Parental perception of children's financial socialization. Financial Counseling and Planning, 5, 127-149.

Edwards, R., Allen, M. A., \& Hayhoe, C. R. (2007). Financial attitudes and family communication about students' finances: the role of sex differences. Communication Reports, 20(2), 90-100. http://dx.doi.org/10.1080/08934210701643719

Engelberg, E., \& Sjoberg, L. (2006). Money attitudes and emotional intelligence. Journal of Applied Social Psychology, 36(8), 2027-2047. http://dx.doi.org/10.1111/j.0021-9029.2006.00092.x

Fear, J., \& O'Brien, J. (2009). Where does the buck stop? Community attitudes to over-lending and over-spending. Australasian Accounting Business and Finance Journal, 3(1), 3-12.

Hilgert, M., Hogarth, J., \& Beverly, S. (2003, July). Household financial management: the connection between knowledge and behavior. Federal Reserve Bulletin, 309-322.

Hong, E. (2005). A study on the money attitudes and the spending behaviors by middle, high, and college students comparison by adolescent stage and sex. Journal of Korean Home Management Association, 23(5), $103-121$.

Kamaruddin, A. R., \& Mokhlis. (2003). Consumer socialization, social structural factors and decision-making styles; a case study of adolescents in Malaysia. International journal of consumer studies. (childhood consumer). http://dx.doi.org/10.1046/j.1470-6431.2003.00297.x

Kezar, A., \& Yang, H. (2010). The importance of financial literacy. About Campus, 14(6), 14-21, Retrieved April 19, 2011, from www.onlinelibrary.wiley.com/doi/10.1002/abc.20004/pdf

Kidwell, B., \& Robert, T. (2004, October). An examination of money management tendencies. Journal of Economic Psychology, 25, 601-616. http://dx.doi.org/10.1016/S0167-4870(03)00073-4

Kim, K. (2003). Money attitudes and personal finance of college students. Journal of Consumption Culture, 6(3), 33-50.

Lyons, A. (2004). A profile of financially at-risk college students. Journal of Consume Affairs, 38(1), 56-80. http://dx.doi.org/10.1111/j.1745-6606.2004.tb00465.x 
Lyons, A. C., Palmer, L., Jayaratne, K. S. U., \& Scherpf, E. (2006). Are We Making the Grade? A National Overview of Financial Education and Program Evaluation. The Journal of Consumer Affairs, 40(2), 208-235. http://dx.doi.org/10.1111/j.1745-6606.2006.00056.x

Mandell, L. (2008). Teaching young dogs old tricks: The effectiveness of financial literacy intervention in pre-high school grades. In T. A. Lucey and K. S. Cooter (Eds.), Financial literacy for children and youth (pp. 221-36). Athens, GA: Digitaltextbooks.biz.

McLeod, J. M., \& O’Keefe, G. J., Jr. (1972). The socialization prospective and communication behavior. In G. Kline, \& P. Tichenor (Eds.), Current perspectives in mass communication research (pp. 121-168). Beverly Hills, CA: Sage.

Morris, L. (2001). An investigation into the financial knowledge levels of New Zealand senior secondary school students. Retrieved October 20, 2010, from http://www.enzt.co.nz/pdf/Financial\%20Literacy.pdf

Moschis, G. P. (1987). Consumer Socialisation. A life-cycle perspective. Lexington, MA.: Lexington.

Noctor, M., Stoney, S., \& Stradling, R. (1992). Financial Literacy. A report prepared for the National Westminster Bank, London.

Pinto, M. B., Parente, D. H., \& Mansfield, P. M. (2005). Information learned from socialization agents: Its relationship to credit card use. Family and Consumer Sciences Research Journal, 33(4). http://dx.doi.org/10.1177/1077727X04274113

Rettig, K. D., \& Mortenson, M. (1986). Household production of financial management competencies. In R. Deacon \& W. Huffman (Eds.), Human Resources Research 1887-1987 (pp. 137-145). Ames, IA: Iowa State University.

Schagen, S., \& Lines, A. (1996). Financial Literacy in Adult Life: A Report to the NatWest Group Charitable Trust. Slough, Berkshire: National Foundation for Educational Research.

Staten, M. E., Elliehausen, G., \& Linquist, E. C. (2002). The impact of credit counseling on subsequent borrower credit usage and payment behaviour, Monograph \#36. Washington, DC: Georgetown University, Credit Research Center. Retrieved October 20, 2010, from http://www.msb.georgetown. edu/prog/crc/pdf/M36.pdf

Varcoe, K. P., Martin, A., Devitto, Z., \& Go, C. (2005). Using a Financial Education Curriculum for Teens. Journal of Financial Counseling and Planning, 16(1).

Vitt, L. A., Anderson, C., Kent, J., Lyter, D. M., Siegenthaler, J. K., \& Ward, J. (2000). Personal finance and the rush to competence: Financial literacy education in the U. S. Washington, DC: Fannie Mae Foundation.

Ward, S. (1974). Consumer socialization. Journal of Consumer Research, 1, 1-16. http://dx.doi.org/10.1086/208584

Widdowson, D., \& Hailwood, K. (2007). Financial literacy and its role in promoting a sound financial system. accessed Retrieved December 20 2009, from http://www.rbnz.govt.nz/research_and_publications/reserve_bank_bulletin/2007/2007jun70_2widdowsonhailwo od.pdf 